\title{
Synthesis and characterization of novel benzo[d][1,3]dioxole substituted organo selenium compounds: $X$-ray structure of 1-((benzo[d][1,3]dioxol-5-yl)methyl)-2-((benzo[d] $[1,3]$ dioxol-6-yl)methyl)diselane
}

\author{
YOGESH NAGPAL ${ }^{\mathrm{a}}$, RAJEEV KUMAR ${ }^{\mathrm{b}, *}$ and K K BHASIN ${ }^{\mathrm{a}}$ \\ a Department of Chemistry and Centre of Advanced Studies in Chemistry, Panjab University, \\ Chandigarh 160 014, India \\ ${ }^{b}$ Department of Environment Studies, Panjab University, Chandigarh 160 014, India \\ e-mail: rajeev@pu.ac.in; yogeshnagpal41081@gmail.com
}

MS received 8 January 2015; revised 20 April 2015; accepted 23 April 2015

\begin{abstract}
An expeditious synthesis of novel organoselenium compounds (2-5) incorporating benzo[d] $[1,3]$ dioxole subunit has been reported. All these newly synthesized compounds have been characterized by elemental analysis and various spectroscopic techniques viz., multinuclear NMR $\left({ }^{1} \mathrm{H},{ }^{13} \mathrm{C}\right.$ and $\left.{ }^{77} \mathrm{Se}\right)$, IR and mass spectrometry. Furthermore, single crystal X-ray crystallographic results and molecular geometry of 1-((benzo[ $d][1,3]$ dioxol-5-yl)methyl)-2-((benzo[ $[d][1,3]$ dioxol-6-yl)methyl)diselane (2) are reported. Thermal decomposition behavior of compound (2) was studied by thermogravimetric analysis.
\end{abstract}

Keywords. Diselenide; monoselenides; benzo $[d][1,3]$ dioxole; X-ray crystal structure.

\section{Introduction}

Organoselenides constitute an intriguing class of compounds that have attracted a constantly growing interest ever since the discovery of ebselen. ${ }^{1}$ In the past decade, various organoselenium compounds have been explored due to their potential applications in the fields of organic synthesis, ${ }^{2}$ pharmaceutics, ${ }^{3}$ ligand chemistry, ${ }^{4}$ semiconducting materials, ${ }^{5}$ biochemistry, ${ }^{6}$ and catalysis. ${ }^{7}$ Additional thrust for research efforts in this field has been endowed by the discoveries of these compounds acting as antioxidants, ${ }^{8,9}$ antitumor,,${ }^{10}$ antiinfective agents, ${ }^{11}$ cytokine inducers, ${ }^{12}$ and immunomodulators. ${ }^{13}$ Recently, an organoselenium compound of the class selenadiazole has caused induced timeand dose-dependent apoptotic cell death in MCF-7 human breast carcinoma cells. ${ }^{14}$ This wide spectrum of attractive utilization has stimulated widespread research efforts aimed at the synthesis and evaluation of novel organoselenides.

Benzodioxole structural motif which is an integral part of many natural products, such as sesamol and piperine occupy a unique place in natural and synthetic organic chemistry. In particular, benzo $[d][1,3]$ dioxole are present in a variety of compounds that possess

*For correspondence important pharmaceutical and biological applications, such as antitumor, ${ }^{15}$ antimicrobial, ${ }^{16} \mathrm{COX}-2$ inhibitor, ${ }^{17}$ and anti-JH. ${ }^{18}$ Recently, a novel bioactive compound of this class, named LASSBio-294, has shown inotropic and vasodilatory effects. ${ }^{19}$

As a part of our interest in the organoselenium chemistry, we are in constant search for novel organoselenides of synthetic as well as biological importance. Recently, we have reported synthesis and physicochemical studies of pyrimidyldichalcogenides. ${ }^{20}$ Beside this, we have also successfully synthesized various novel 2-aryl/pyridylselenoethanoic acids and C-3 selenium substituted $\beta$-lactams starting from diselenides. ${ }^{21,22}$ Further, biological evaluation of various novel organoselenides synthesized in our laboratory is underway.

Enthused by the pharmacological applications of organoselenides and benzo[ $d][1,3]$ dioxole and to build upon our previous studies as well, we sought to synthesize some hitherto unknown organoselenium compounds containing benzo[ $[d][1,3]$ dioxole scaffold as an integral unit. Herein we wish to report the results of our studies towards the successful synthesis, characterization and structural elucidation of these compounds. In addition, single crystal X-ray and thermogravimetric analysis of compound 1-((benzo[d] [1,3]dioxol-5-yl)methyl)-2-((benzo[d][1,3]dioxol-6-yl) methyl)diselane (2) has been described. 


\section{Experimental}

\subsection{General methods}

All the reactions were carried out under dry and deoxygenated nitrogen atmosphere. Sodium borohydride (Qualigen), Rongalite (Qualigen), absolute alcohol (TEDIA) and all other commercially available compounds/reagents were of analytical grade and used without further purification.

Melting points were determined in an open capillary on melting point apparatus and are uncorrected. Infrared spectra were taken on a Perkin-Elmer 1430 (FTIR) spectrophotometer $\left(v_{\max }\right.$ in $\left.\mathrm{cm}^{-1}\right) .{ }^{1} \mathrm{H}(300$ $\mathrm{MHz}),{ }^{13} \mathrm{C}(75 \mathrm{MHz})$ and ${ }^{77} \mathrm{Se}(57 \mathrm{MHz}) \mathrm{NMR}$ spectra were recorded on JEOL AL 300 (300 MHz) spectrometer. Chemical shifts are given in ppm relative to $\mathrm{Me}_{4} \mathrm{Si}$ as an internal standard ( $\left.\delta=0 \mathrm{ppm}\right)$ for ${ }^{1} \mathrm{H}$ NMR, $\mathrm{CDCl}_{3}(\delta=77.0 \mathrm{ppm})$ for ${ }^{13} \mathrm{C}$ NMR spectra and $\mathrm{Me}_{2} \mathrm{Se}$ $(\delta=0 \mathrm{ppm})$ for ${ }^{77} \mathrm{Se}$ NMR spectra. The mass spectra (EI) were obtained using QTOF mass spectrometer. The elemental analysis $(\mathrm{C}, \mathrm{H})$ were recorded on Flash EA 112 elemental analyzer. The thermogravimetric (TGA) of the solid compound (2) was performed using a STA 6000 thermogravimetric analyser (Perkin-Elmer) at a heating rate of $5^{\circ} \mathrm{C} \mathrm{min}{ }^{-1}$ under nitrogen flow and heating programme $35-710^{\circ} \mathrm{C}$. Column chromatography was performed using Merck Silica Gel (60-120 mesh) using ethyl acetate-hexanes (2:98) as an eluent system. Analytical thin-layer chromatography (TLC) was performed using Merck Silica Gel G using ethyl acetatehexanes (4:94) as an eluent system. For visualization, TLC plates were stained with iodine vapors.

\subsection{Crystal structure determination and refinement}

Intensity data for compound (2) was collected using a Smart-CCD-1000 Bruker diffractometer $\left(\mathrm{Mo} \mathrm{K}_{\alpha}\right.$ radiation, $\lambda 0.71069 \AA$ ) equipped with a graphite monochromator. Data for compound (2) were measured at 100 $\mathrm{K}$. The $\omega$ scan technique was employed to measure intensities. The intensity of data set was corrected for Lorentz and polarization effects. Absorption effects were corrected using the program SADABS. ${ }^{23}$ The crystal structure was solved by direct methods. Crystallographic programs used for structure solution and refinement were those in SHELX97. ${ }^{24}$ Scattering factors were those provided with the SHELX program system. Missing atoms were located in the difference Fourier map and included in subsequent refinement cycles. The structures were refined by full-matrix leastsquares refinement on $\mathrm{F}^{2}$, using anisotropic displacement parameters for all non-hydrogen atoms.
2.3 Preparation of $1-(($ benzo $[d][1,3]$ dioxol-5-yl) methyl)-2-((benzo[d][1,3]dioxol-6-yl) methyl)diselane (2)

To a vigorously stirred solution of selenium $(1.58 \mathrm{~g}, 20$ $\mathrm{mmol})$ in absolute ethanol sodium borohydride $(0.70 \mathrm{~g}$, $18.5 \mathrm{mmol}$ ) was added in three portion under ice water bath. Stirring was continued until all the selenium had dissolved and a colorless solution resulted in. To this solution piperidine hydrochloride $(2.07 \mathrm{~g}, 17 \mathrm{mmol})$ was added followed by the addition of piperonal (2.34 $\mathrm{g}, 15.6 \mathrm{mmol}$ ). The reaction mixture was subjected to strong refluxing for $1 \mathrm{~h}$ and thereafter cooled to room temperature. Addition of sodium borohydride $(0.15 \mathrm{~g}, 4$ $\mathrm{mmol}$ ) in small portions resulted in a vigorous reaction and color of the solution changes from brown to yelloworange. Reaction mixture was washed with excess of water, extracted with chloroform $(3 \times 20 \mathrm{~mL})$ and dried over anhydrous sodium sulfate. Solvent was evaporated on rota-evaporator to yield reddish brown crude product which on column chromatographic purification using ethyl acetate-hexane (2:98) as an eluent system furnishes yellow powder. Thereafter the resulting yellow powder was crystallized in a mixture of DCM-hexane (1:3) to obtain colourless crystalline solid (2).

\subsection{General procedure for the synthesis of unsymmetrical monoselenides (3-5)}

2.4a Using sodium borohydride methodology: To a solution of 1-((benzo[ $d][1,3]$ dioxol-5-yl)methyl)-2((benzo[ $d][1,3]$ dioxol-6-yl)methyl)diselane (2) $(0.43 \mathrm{~g}$, $1 \mathrm{mmol})$ in $20 \mathrm{~mL}$ ethanol sodium borohydride $(0.1$ $\mathrm{g}, 2.3 \mathrm{mmol}$ ) was added in parts with continuous stirring. To the reaction mixture $2 \mathrm{mmol}$ of alkylating agent (RX) diluted with equal volume of ethanol was added drop wise under ice water bath. On completion of reaction, ethanol was removed under reduced pressure and mixture was extracted with DCM, washed with water and dried over anhydrous sodium sulfate. Solvent was evaporated on rota-evaporator and the crude product was purified by column chromatography using ethyl acetate-hexane (2:98) as an eluent.

2.4b Using rongalite methodology: To a well-stirred solution of diselenide (2) $(0.43 \mathrm{~g}, 1 \mathrm{mmol})$ in $25 \mathrm{~mL}$ ethanol was added rongalite $(0.71 \mathrm{~g}, 6 \mathrm{mmol})$ and $\mathrm{K}_{2} \mathrm{CO}_{3}(0.55 \mathrm{~g}, 4 \mathrm{mmol})$ followed by the addition of 2 mmol of alkylating agent (RX). The reaction mixture was stirred at room temperature and progress of reaction was monitored by TLC. After the completion of reaction, quenching of reaction mixture was done with 
water. Reaction mixture was extracted by $\mathrm{CH}_{2} \mathrm{Cl}_{2}$ (2 $\times 20 \mathrm{~mL}$ ) and organic layer was dried over anhydrous sodium sulfate. After solvent evaporation on rota evaporator the crude product was purified by column chromatography on silica gel using ethyl acetate-hexane (2:98) as an eluent system.

\subsection{Physical and spectral data}

2.5a 1-((benzo[d][1,3]dioxol-5-yl)methyl)-2-((benzo [d][1,3]dioxol-6yl)methyl)diselane $\left[\left(\mathrm{C}_{7} \mathrm{H}_{5} \mathrm{O}_{2}\right) \mathrm{CH}_{2}\right.$ $\left.\mathrm{SeSeCH}_{2}\left(\mathrm{C}_{7} \mathrm{H}_{5} \mathrm{O}_{2}\right)\right](2)$ : Colorless crystalline solid, yield: $87 \%$; M.p. $68-70^{\circ} \mathrm{C}$; IR (KBr) $v_{\max } / \mathrm{cm}^{-1}$ : 3364.4 , 2917.1, 1846.8, 1605.7, 1486.0, 1245.9, 1169.3, 1041.4, 855.5, 642.7. ${ }^{1} \mathrm{H}$ NMR $(300 \mathrm{MHz}$, $\left.\mathrm{CDCl}_{3}, \delta, \mathrm{ppm}\right): 6.65-6.58(\mathrm{~m}, 6 \mathrm{H}), 5.86(\mathrm{~s}, 4 \mathrm{H}), 3.75$ (s, 4H); ${ }^{13} \mathrm{C} \mathrm{NMR}\left(100 \mathrm{MHz}, \mathrm{CDCl}_{3}, \delta, \mathrm{ppm}\right): 147.68$, $146.84,132.77,122.27,109.39,108.19,108.15$, 101.01, 32.89; ${ }^{77} \mathrm{Se} \mathrm{NMR}\left(\left\{{ }^{1} \mathrm{H}\right\}, 57 \mathrm{MHz}, \mathrm{CDCl}_{3}\right.$, $\delta, \mathrm{ppm}): 403.1 ; \operatorname{LCMS}(\mathrm{m} / \mathrm{z}): 429\left(27 \%,[\mathrm{M}+1]^{+}\right)$, $430\left(7 \%,[\mathrm{M}+2]^{+}\right), 413\left(26 \%,\left[\mathrm{C}_{16} \mathrm{H}_{14} \mathrm{O}_{3} \mathrm{Se}_{2}\right]^{+}\right), 257$ $\left(100 \%,\left[\mathrm{C}_{14} \mathrm{H}_{10} \mathrm{Se}\right]^{+}\right), 339\left(24 \%,\left[\mathrm{C}_{14} \mathrm{H}_{12} \mathrm{Se}_{2}\right]^{+}\right), 293$ (33\%, $\left[\mathrm{C}_{8} \mathrm{H}_{7} \mathrm{Se}_{2}\right]^{+}$); Anal. Calcd. For $\mathrm{C}_{16} \mathrm{H}_{14} \mathrm{O}_{4} \mathrm{Se}_{2}$ : C-44.88; H-3.30; Found: C-44.69; H-3.08\%.

2.5b 5-((methylselanyl)methyl)benzo[d][1,3]dioxole [( $\left.\mathrm{C}_{7} \mathrm{H}_{5} \mathrm{O}_{2}\right) \mathrm{CH}_{2} \mathrm{SeCH}_{3}$ ] (3): Colorless oil, yield: 68;. IR (KBr) $v_{\max } / \mathrm{cm}^{-1}: 3428.5,2922.3,2775.0,2360.19$, $1636.08,1500.34,1486.8,1442.29,1357.3,1247.8$, $1210.4,1182.0,1093.6,1038.7,927.7,860.6,810.0 ;{ }^{1} \mathrm{H}$ NMR (300MHz, $\left.\mathrm{CDCl}_{3}, \delta, \mathrm{ppm}\right): \delta 6.68(\mathrm{~s}, 1 \mathrm{H}), 6.59-$ $6.58(\mathrm{~d}, 2 \mathrm{H}, 1.5 \mathrm{~Hz}), 5.83(\mathrm{~s}, 2 \mathrm{H}), 3.56(\mathrm{~s}, 2 \mathrm{H}), 1.18$ (s, 3H). ${ }^{13} \mathrm{C}$ NMR $\left(100 \mathrm{MHz}, \mathrm{CDCl}_{3}, \delta, \mathrm{ppm}\right): 147.72$, 146.37, 132.86, 121.82, 109.14, 107.85, 100.84, 28.30, 4.07; LCMS $(m / z): 135\left(16 \%,\left[\mathrm{C}_{8} \mathrm{H}_{7} \mathrm{O}_{2}\right]^{+}\right), 335(19 \%$, $\left.\left[\mathrm{C}_{15} \mathrm{H}_{12} \mathrm{O}_{4} \mathrm{Se}\right]^{+}\right), 292\left(17 \%,\left[\mathrm{C}_{14} \mathrm{O}_{2} \mathrm{Se}\right]^{+}\right), 247(8 \%$, $\left.\left[\mathrm{C}_{13} \mathrm{H}_{12} \mathrm{Se}\right]^{+}\right)$.

\section{5c 5-((allylselanyl)methyl)benzo[d][1,3]dioxole} [ $\left.\left(\mathrm{C}_{7} \mathrm{H}_{5} \mathrm{O}_{2}\right) \mathrm{CH}_{2} \mathrm{SeCH}_{2} \mathrm{CH}=\mathrm{CH}_{2}\right]$ (4): Colorless oil, yield: 73\%; IR (KBr) $v_{\max } / \mathrm{cm}^{-1}$ : 3420.3, 3079.18, 1248.6, 694.9; ${ }^{1} \mathrm{H}$ NMR (300MHz, $\left.\mathrm{CDCl}_{3}, \delta, \mathrm{ppm}\right)$ : 6.69 (s, 1H), 6.59-6.58 (d, 2H, 0.9 Hz), 5.85-5.71 (m, $1 \mathrm{H}), 5.82(\mathrm{~s}, 2 \mathrm{H}), 4.96-4.91(\mathrm{~d}, 2 \mathrm{H}, 14.7 \mathrm{~Hz}), 3.54$ (s, 2H), 3.02-2.99 (d, 2H, 17.5 Hz); ${ }^{13} \mathrm{C}$ NMR (100 $\mathrm{MHz}, \mathrm{CDCl}_{3}, \delta$, ppm): 147.68, 146.31, 134.98, 132.81, 121.95, 116.30, 109.36, 107.81, 100.99, 33.78, 26.53; LCMS $(m / z): 135\left(100 \%,\left[\mathrm{C}_{8} \mathrm{H}_{7} \mathrm{O}_{2}\right]^{+}\right), 413(14 \%$, $\left[\mathrm{C}_{15} \mathrm{H}_{12} \mathrm{O}_{4} \mathrm{Se}_{2}\right]^{+}$).

$2.5 \mathrm{~d}$ 2-((benzo[d][1,3]dioxol-6-yl)methylselanyl)-4chloropyrimidine $\left[\left(\mathrm{C}_{7} \mathrm{H}_{5} \mathrm{O}_{2}\right) \mathrm{CH}_{2} \mathrm{Se}\left(\mathrm{C}_{4} \mathrm{H}_{2} \mathrm{ClN}_{2}\right)\right]$ (5): Semisolid, yield 64\%; IR (KBr) $v_{\max } / \mathrm{cm}^{-1}: 3434.1$,
2892.1, 2775.0, 1250.4; ${ }^{1} \mathrm{H}$ NMR $\left(300 \mathrm{MHz}, \mathrm{CDCl}_{3}\right.$, $\delta$, ppm): 8.04-8.02 (d, 1H, 5.4 Hz), 7.09-7.07 (d, $1 \mathrm{H}, 5.4 \mathrm{~Hz}), 6.77-6.74(\mathrm{~d}, 2 \mathrm{H}, 7.5 \mathrm{~Hz}), 6.61-6.59$ (d, 1H, $8.4 \mathrm{~Hz}), 5.82$ (s, 2H), $4.30(\mathrm{~s}, 2 \mathrm{H}) ;{ }^{13} \mathrm{C} \mathrm{NMR}$ (100 MHz, $\mathrm{CDCl}_{3}, \delta, \mathrm{ppm}$ ): 171.27, 161.04, 156.00, 147.71, 130.86, 122.42, 120.55, 109.42, 100.93, 29.66; LCMS $(m / z): 135\left(54 \%,\left[\mathrm{C}_{8} \mathrm{H}_{7} \mathrm{O}_{2}\right]^{+}\right), 297(6 \%$, $\left.\left[\mathrm{C}_{11} \mathrm{H}_{7} \mathrm{~N}_{2} \mathrm{OSe}\right]^{+}\right), 121\left(38 \%,\left[\mathrm{C}_{7} \mathrm{H}_{5} \mathrm{O}_{2}\right]^{+}\right), 413(8 \%$, $\left[\mathrm{C}_{10} \mathrm{H}_{8} \mathrm{C}_{12} \mathrm{~N}_{4} \mathrm{Se}_{2}\right]^{+}$).

\section{Results and Discussion}

\subsection{Synthesis}

Diorganyl diselenides are versatile building blocks for large number of seleno-organic compounds. ${ }^{25-27}$ In pursuance of our study on diorganyl diselenides and its derivatives, our initial emphasis was on finding a convenient and efficient route to benzo $[d][1,3]$ dioxole incorporated diselenide. Through an extensive search for literature precedents, a single report on the synthesis of diselenide of benzo[d][1,3]dioxole has been reported by Sadek et $a .^{28}$ They had synthesized symmetrical diselenide 5-(2-(benzo[d][1,3]dioxol-6-yl) diselanyl) benzo[ $d][1,3]$ dioxole using 5-bromobenzo $[d][1,3]$ dioxole via Grignard methodology during their course of study on the synthesis of selenium labeled radiopharmaceuticals. In light of this reports we devise a direct and concise method to furnish novel benzo $[d][1,3]$ dioxole incorporated diselenide using stable and readily available starting material.

Our initial synthetic endeavor begins with the synthesis of 1-((benzo[d][1,3]dioxol-5-yl)methyl)-2((benzo[ $d][1,3]$ dioxol-6-yl)methyl)diselane (2) by the treatment of piperonal (1) with NaHSe in the presence of piperidine hydrochloride, and ethanol as solvent using reported procedure. ${ }^{29}$ Diselenide (2) thus synthesized was transformed into various synthetically important unsymmetrical monoselenides (3-5) by cleavage of $\mathrm{Se}-\mathrm{Se}$ bond with sodium borohydride or rongalite followed by addition of suitable electrophiles (scheme 1). Comparative study using sodium borohydride and rongalite has been performed. The reaction proceeds much faster when sodium borohydride is used for cleavage in comparison to rongalite and it can be ascribed to nucleophilic behavior of sodium borohydride. Structures of all the newly synthesized selenium compounds were unambiguously identified by NMR, IR, mass spectroscopy and elemental analysis. Furthermore, representative solid-state structure of (2) was determined using single crystal X-ray diffraction technique. 


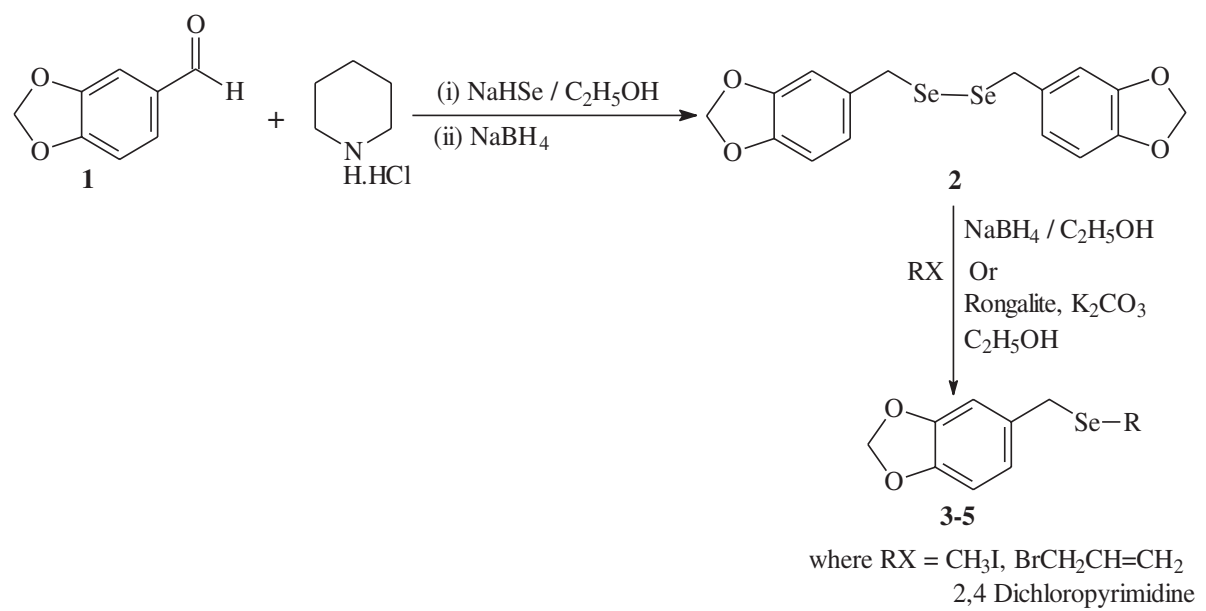

Scheme 1. Synthesis of 1-((benzo $[d][1,3]$ dioxol-5-yl)methyl)-2-((benzo $[d][1,3]$ dioxol6-yl)methyl)diselane (2) and its unsymmetrical analogues.

The compound (2) shows tendency to decompose in solution whereas in crystalline form it remains stable for months. Therefore we performed thermogravimetric analysis (TGA) to study the decomposition behavior of this compound. The novel diselenide (2) is versatile synthon as it is amenable to great number of structural modifications and it holds great promise as potential GPx mimic because of its ability to exhibit intermolecular nonbonding interactions between selenium and oxygen. Future studies may well expand the synthetic as well as biochemical aspects of this work to include more complicated structures, which are in principle possible.

\subsection{Spectroscopic Studies}

The structures of all these novel compounds (2-5) were established by elemental analysis and various spectroscopic techniques. The formation of product (2) was clearly indicated from the ${ }^{1} \mathrm{H}$ NMR spectrum, by the disappearance of the signal corresponding to aldehydic proton of starting substrate and appearance of singlet of methylene protons at $\delta 3.75$. Presence of benzo $[d][1,3]$ dioxole moiety in product was confirmed by the singlet at $\delta 5.86$ typical for its methylene protons. The structures of all the monoselenides (3-5) synthesized are well in agreement with ${ }^{1} \mathrm{H}$ NMR spectra which in each case showed characteristic peaks of benzo $[d][1,3]$ dioxole alongwith the singlet of seleno substituted methine protons. The seleno methine protons $\left[\left(\mathrm{C}_{7} \mathrm{H}_{5} \mathrm{O}_{2}\right) \mathrm{CH}_{2} \mathrm{Se}-\right]$ of monoselenides $(\mathbf{3 , 4})$ experience an upfield shift of almost $\delta 0.25 \mathrm{ppm}$ in comparison with the starting diselenide (2). But this trend reverses as the significant downfield shift of $\delta 0.55$ ppm is observed in monoselenide (5) in comparison to the parent diselenide (2). Moreover the various electrophiles hooked to selenium exhibit their respective characteristic peaks to substantiate the formation of products. For instance, a singlet at $\delta 1.18$ corresponding to three methylene protons confirms formation of (3). Similarly, appearance of two doublets each integrating for $1 \mathrm{H}$ at $\delta 8.02-8.04$ and 7.07-7.09 respectively corroborates the formation of pyrimidyl containing monoselenide (5) by replacing the second position of 2,4-dichloropyrimidine which is further correlated with the literature report. ${ }^{30}$

In the ${ }^{13} \mathrm{C}$ NMR spectra of compounds (2-5), the carbon signals of aromatic carbons of benzodioxole fall in the range of $\delta 107.8-147.7 \mathrm{ppm}$ along with the methylene carbon of dioxole ring and the peak corresponding to seleno substituted methine proton $\left[\left(\mathrm{C}_{7} \mathrm{H}_{5} \mathrm{O}_{2}\right) \mathrm{CH}_{2} \mathrm{Se}-\right.$ ] comes in the range of $\delta 28.3-33.7$ ppm whereas maximum deshielded in (4). ${ }^{13} \mathrm{C}$ NMR spectroscopic results well support the formulation of monoselenides (3-5). A ${ }^{77} \mathrm{Se} \mathrm{NMR}$ result of compound (2) in $\mathrm{CDCl}_{3}$ reveals a single sharp peak at $\delta 403.1 \mathrm{ppm}$ which corresponds to the formation of symmetrical diselenide.

IR spectra of liquid samples were recorded in the range of $4000-400 \mathrm{~cm}^{-1}$ as neat mulls between $\mathrm{KBr}$ plates, whereas solid compounds were compressed into $\mathrm{KBr}$ discs for study. The compounds exhibit many similar bands due to structural similarity. The sharp peak around $1245 \mathrm{~cm}^{-1}$ is assigned to $\mathrm{C}-\mathrm{O}$ functionality of dioxole ring. Some characteristics peaks of respective compounds are mentioned in experimental section.

The electrospray mass spectrum of (2) indicates the corresponding molecular ion peaks centered at $\mathrm{m} / \mathrm{z}=$ 429 and 430 corresponding to $[\mathrm{M}+1]^{+}$and $[\mathrm{M}+2]^{+}$ ion respectively. The fragmentation pattern of (2) well 
supports the expected structure of compound as shown in figure 1. The EI-MS spectra displays peaks at $\mathrm{m} / \mathrm{z}$ 293 (33\%), 413 (26\%), 339 (24\%). However, the base peak in (2) corresponds to the fragment of dibenzylmonoselenide $m / z=257$ (100\%). In case of unsymmetrical monoselenides (3-5) molecular ion peak is not observed owing to the extensive dissociation of these compounds. However, the fragment ion peaks identified in each case shows behavioral resemblances to their respective molecular ions characteristics of that particular compound. A peak at $m / z=135$ is observed in case of all the monoselenides (3-5) corresponding to $\left[\mathrm{C}_{8} \mathrm{H}_{7} \mathrm{O}_{2}\right]^{+}$fragment formed by the cleavage of $\mathrm{C}-$ Se bond. Also, in case of monoselenide (4) the peak corresponding to this fragment ion (i.e. $\left[\mathrm{C}_{8} \mathrm{H}_{7} \mathrm{O}_{2}\right]^{+}$) is base peak. Various other peaks identified are listed in experimental section. Mass fragmentation pattern of compound (2) shown in supplementary information (figure 4).

\subsection{Thermogravimetric analysis}

The thermogravimetric (TG) and derivative curve (DTG), which characterize thermal decomposition of compound (2) in nitrogen atmosphere at a rate of $5^{\circ} \mathrm{C}$ $\mathrm{min}^{-1}$ is given in figure 2 . The results revealed that the compound decomposes in several thermal events. The TG curve of (2) consists of mainly four steps in the temperature range of $215-285,300-363,363-455$ and $455-527^{\circ} \mathrm{C}$. The maximum loss of mass is observed in the very first step which seems to be consistent with the evolution of $\mathrm{CH}_{2} \mathrm{Se}_{2}$ fragment (40\%). Afterwards a progressive decomposition sets in until $527^{\circ} \mathrm{C}$ where a constant mass was achieved indicating the residual $\mathrm{C}_{4} \mathrm{H}_{7}$

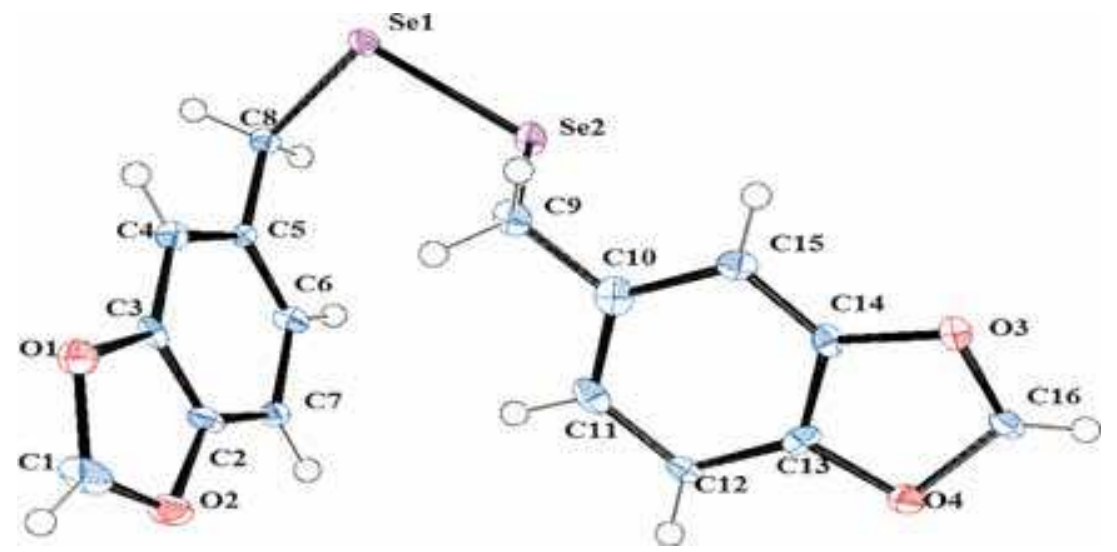

Figure 1. ORTEP diagram showing the conformation and atom numbering scheme of (2).

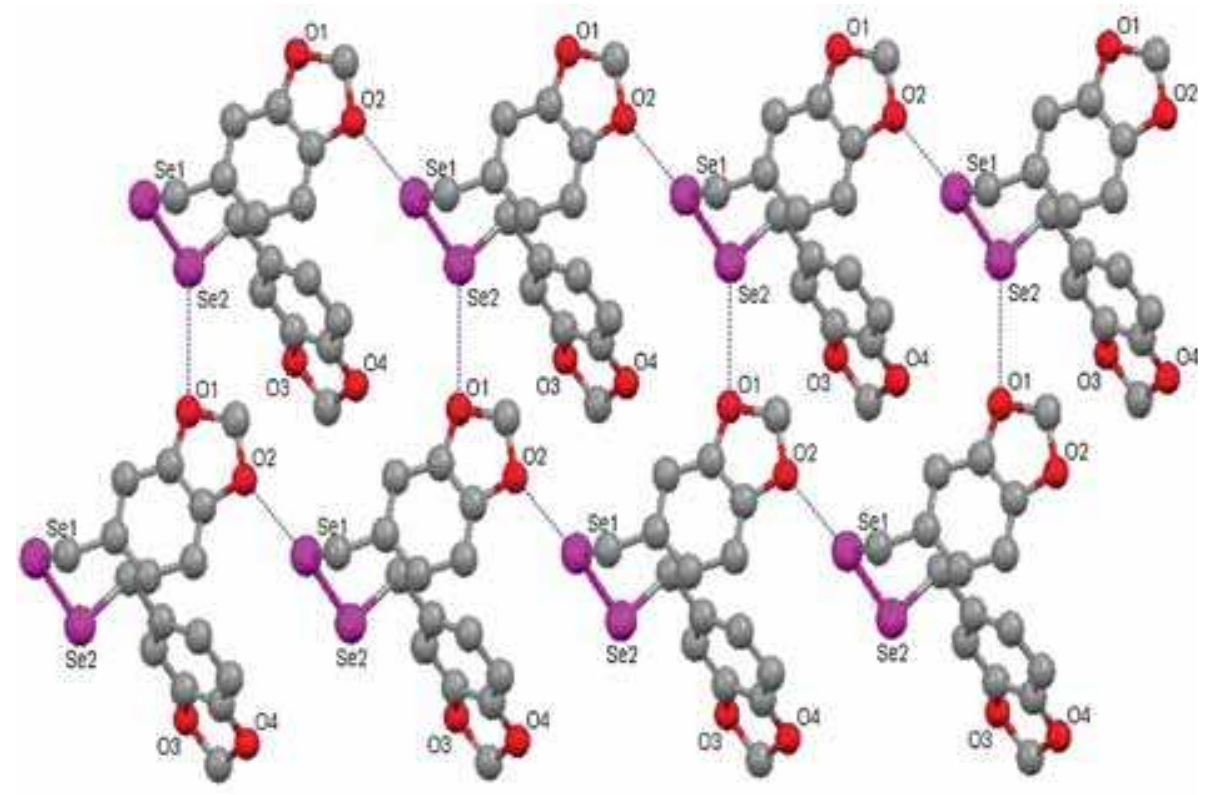

Figure 2. Network of Intermolecular Se . O nonbonding interactions of (2) (hydrogen atoms are omitted for clarity). 
Table 1. Selected metric parameters of compound (2).

\begin{tabular}{|c|c|}
\hline & Compound \\
\hline Empirical formula & $\mathrm{C}_{16} \mathrm{H}_{12} \mathrm{O}_{4} \mathrm{Se}_{2}$ \\
\hline Formula weight (g/mol) & 426.18 \\
\hline Temperature (K) & $100(2)$ \\
\hline Diffractometer used & Bruker Smart Apex \\
\hline $\begin{array}{l}\text { Radiation used, } \\
\lambda \operatorname{Mo} K \alpha(\AA)\end{array}$ & 0.71069 \\
\hline $\begin{array}{l}\text { Crystal system / } \\
\text { space group }\end{array}$ & Triclinic, $\mathrm{P}-1$ \\
\hline Unit cell dimensions & \\
\hline$a(\AA)$ & $8.105(5)$ \\
\hline$b(\AA)$ & $9.104(5)$ \\
\hline$c(\AA)$ & $10.966(5)$ \\
\hline$\alpha\left(^{\circ}\right)$ & $93.426(5)$ \\
\hline$\beta\left(^{\circ}\right)$ & $93.043(5)$ \\
\hline$\gamma\left({ }^{\circ}\right)$ & $110.575(5)$ \\
\hline$V\left(\AA^{3}\right)$ & $753.8(7)$ \\
\hline $\begin{array}{l}Z \text {, calculated density } \\
\left(\mathrm{Mg} / \mathrm{m}^{3}\right)\end{array}$ & 2 \\
\hline $\begin{array}{l}\text { Absorption coefficient } \\
\left(\mathrm{mm}^{-1}\right)\end{array}$ & 4.919 \\
\hline$F(000)$ & 416 \\
\hline Crystal size $\left(\mathrm{mm}^{3}\right)$ & $0.13 \times 0.06 \times 0.03$ \\
\hline $\begin{array}{l}\theta \text { range for data } \\
\text { collection }\left(^{\circ}\right)\end{array}$ & $2.69-26.00$ \\
\hline Index ranges & $\begin{array}{l}-7 \leq \mathrm{h} \leq 9 \\
-10 \leq \mathrm{k} \leq 11 \\
-13 \leq 1 \leq 13\end{array}$ \\
\hline $\begin{array}{l}\text { Reflection. Collected/ } \\
\text { unique }\end{array}$ & $419 \overline{3 / 2} 8 \overline{82}$ \\
\hline$\left[R_{\text {(int) }}\right]$ & 0.0310 \\
\hline $\begin{array}{l}\text { Reflection with } \\
{[I>2 \sigma(I)]}\end{array}$ & 2372 \\
\hline Refinement method & Full-matrix least- square on $F^{2}$ \\
\hline $\begin{array}{l}\text { Final } R \text { indices, } \\
\quad[I>2 \sigma(I)]\end{array}$ & $R_{1}=0.0568, w R_{2}=0.1495$ \\
\hline$R$ indices [all data] & $R_{1}=0.0686, w R_{2}=0.1705$ \\
\hline $\begin{array}{l}\text { Largest difference in peak } \\
\text { and hole }\left(\mathrm{e} \AA^{-3}\right)\end{array}$ & 1.491 and -2.541 \\
\hline
\end{tabular}

(13\%) radical. During this thermal analytical studies various other fragments like $\mathrm{C}_{4} \mathrm{H}_{5}, \mathrm{C}_{3} \mathrm{H}_{3} \mathrm{O}_{2} \mathrm{C}_{4} \mathrm{H}_{5} \mathrm{O}_{2}$ corresponding to the mass loss of 12,16 and $20 \%$ respectively are also observed. TGA and DTG thermogram of
Table 3. Intermolecular non-bonded short contacts of compound (2).

\begin{tabular}{lc}
\hline Intermolecular Non-bonded short contacts & Length $(\AA)^{\mathrm{a}}$ \\
\hline $\mathrm{Se}(1) \cdots \mathrm{O}(2)$ & $3.06(4)$ \\
$\mathrm{Se}(2) \cdots \mathrm{O}(1)$ & $3.30(6)$ \\
$\mathrm{Se}(2) \cdots \mathrm{H}(8 \mathrm{~B})$ & $3.08(0)$ \\
$\mathrm{Se}(1) \cdots \mathrm{H}(15)$ & $3.01(6)$ \\
$\mathrm{O}(2) \cdots \mathrm{H}(8 \mathrm{~A})$ & $2.60(7)$
\end{tabular}

${ }^{\mathrm{a}}$ Estimated standard deviation in least significant figure are given in parentheses

compound (2) in nitrogen at heating rate of $5^{\circ} \mathrm{C} \mathrm{min}^{-1}$ (figure 6).

\section{$3.4 \quad X$-ray discussion}

The crystal structure of 1-((benzo[d][1,3]dioxol-5-yl) methyl)-2-((benzo[d][1,3]dioxol-6-yl)methyl)diselane (2) was established by single crystal X-ray crystallographic analysis. A prospective view of the molecular structure with atom numbering scheme has been given in figure 1. Intermolecular Se... O nonbonding interactions network is shown in figure 2 (hydrogen atoms are omitted for clarity). All the relevant information about data collection and metric parameters has been listed in table 1 . Selected bond lengths $[\AA]$, bond angles $\left[^{\circ}\right]$ and torsion angles $\left[{ }^{\circ}\right]$ are presented in table 2. Important intermolecular short contacts have been listed in table 3.

The Se-Se bond distance of 2.311(12) ̊ relates well with the corresponding distances reported for other diselenides, which ranges from 2.29 to $2.39 \AA$ (Pauling scale). The Se-C bond length [Se(1)-C(1) 1.994(6) $\AA$ ] is also in agreement with the value of $1.93 \AA$ suggested by Pauling a typical value of other diselenides. ${ }^{31}$ The average $\mathrm{C}-\mathrm{C}$ bond length in phenyl ring in (2) is 1.388 $\AA$. Analysis of bond angles reveals geometry around selenium as ' $\mathbf{V}$ ' shaped. An interesting feature of this

Table 2. Selected bond parameters of (2).

\begin{tabular}{|c|c|c|c|c|c|}
\hline \multicolumn{2}{|c|}{ Bond length $(\AA)^{\mathrm{a}}$} & \multicolumn{2}{|l|}{ Bond angle $\left({ }^{\circ}\right)^{\mathrm{a}}$} & \multicolumn{2}{|l|}{ Torsion angles $\left[^{\circ}\right]^{\mathrm{a}}$} \\
\hline $\operatorname{Se}(1)-C(8)$ & $1.994(6)$ & $\mathrm{C}(8)-\mathrm{Se}(1)-\operatorname{Se}(2)$ & $100.29(17)$ & $\mathrm{C}(8)-\mathrm{Se}(1)-\mathrm{Se}(2)-\mathrm{C}(9)$ & $-86.5(3)$ \\
\hline $\operatorname{Se}(1)-\operatorname{Se}(2)$ & $2.311(12)$ & $\mathrm{C}(9)-\mathrm{Se}(2)-\operatorname{Se}(1)$ & $104.25(19)$ & $\mathrm{O}(1)-\mathrm{C}(3)-\mathrm{C}(4)-\mathrm{C}(5)$ & $-179.2(5)$ \\
\hline $\operatorname{Se}(2)-C(9)$ & $1.995(6)$ & $\mathrm{C}(3)-\mathrm{O}(1)-\mathrm{C}(1)$ & $105.0(4)$ & $\mathrm{C}(11)-\mathrm{C}(10)-\mathrm{C}(9)-\mathrm{Se}(2)$ & $-97.5(5)$ \\
\hline $\mathrm{O}(1)-\mathrm{C}(3)$ & $1.379(7)$ & $\mathrm{C}(13)-\mathrm{O}(4)-\mathrm{C}(16)$ & $104.3(4)$ & $\mathrm{C}(15)-\mathrm{C}(10)-\mathrm{C}(9)-\mathrm{Se}(2)$ & 81.4(6) \\
\hline $\mathrm{O}(1)-\mathrm{C}(1)$ & $1.436(7)$ & $\mathrm{C}(14)-\mathrm{O}(3)-\mathrm{C}(16)$ & $105.0(5)$ & $\mathrm{Se}(1)-\mathrm{Se}(2)-\mathrm{C}(9)-\mathrm{C}(10)$ & $171.4(4)$ \\
\hline $\mathrm{O}(4)-\mathrm{C}(16)$ & $1.446(7)$ & $\mathrm{C}(7)-\mathrm{C}(2)-\mathrm{O}(2)$ & $128.2(6)$ & $\mathrm{C}(6)-\mathrm{C}(5)-\mathrm{C}(8)-\mathrm{Se}(1)$ & $-111.2(5)$ \\
\hline $\mathrm{C}(2)-\mathrm{O}(2)$ & $1.398(7)$ & $\mathrm{C}(11)-\mathrm{C}(10)-\mathrm{C}(9)$ & $119.8(6)$ & $\mathrm{C}(4)-\mathrm{C}(5)-\mathrm{C}(8)-\mathrm{Se}(1)$ & $68.5(6)$ \\
\hline \multirow[t]{2}{*}{$\mathrm{O}(2)-\mathrm{C}(1)$} & $1.426(8)$ & $\mathrm{C}(10)-\mathrm{C}(9)-\mathrm{Se}(2)$ & $104.7(4)$ & $\operatorname{Se}(2)-\operatorname{Se}(1)-C(8)-C(5)$ & $58.3(4)$ \\
\hline & & $\mathrm{C}(5)-\mathrm{C}(8)-\mathrm{Se}(1)$ & $113.8(4)$ & $\mathrm{C}(6)-\mathrm{C}(5)-\mathrm{C}(8)-\mathrm{Se}(1)$ & $-111.2(5)$ \\
\hline
\end{tabular}

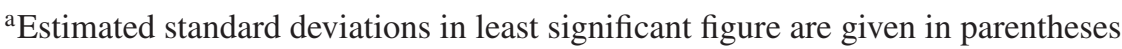


compound is presence of selenium oxygen nonbonding interactions which makes this diselenide potential candidate for Glutathione peroxidase (GPx) activity in accordance with the studies conducted by Thomas Wirth and Wilson et al. ${ }^{32,33}$ The structure reported here adds to the examples in which $\mathrm{Se}$.. O nonbonding interactions are present. The Intermolecular distances of $\mathrm{Se}(1) \cdots \mathrm{O}(2)$ and $\mathrm{Se}(2) \cdots \mathrm{O}(1)$ are 3.064 and 3.306 respectively. In addition to that intermolecular Se $\cdots \mathrm{H}$ and $\mathrm{O} \cdots \mathrm{H}$ short contacts are also present and their value is listed in table 3 . The crystal packing of compound reveals presence of two atoms per unit cell. Nonbonding interactions are not present within the unit cell of crystal lattice. The torsional angle of $-86.55^{\circ} \mathrm{C}$ between $\mathrm{C}(8)-\mathrm{Se}(1)-\mathrm{Se}(2)-\mathrm{C}(9)$ clearly indicates skew conformation.

\section{Conclusions}

In conclusion, we developed a direct and concise method to furnish novel benzo[ $d][1,3]$ dioxole-incorporated diselenide using stable and readily available starting materials. Our initial synthetic endeavor began with the synthesis of $1-(($ benzo $[d][1,3]$ dioxol5-yl)methyl)-2-((benzo[ $d][1,3]$ dioxol-6-yl)methyl) diselane (2) by the treatment of piperonal (1) with NaHSe in the presence of piperidine hydrochloride, and ethanol as solvent using reported procedure. Diselenide (2), thus synthesized, was transformed into various synthetically important unsymmetrical monoselenides (3-5) by cleavage of Se-Se bond with sodium borohydride or rongalite followed by addition of suitable electrophiles. Comparative study using sodium borohydride and rongalite has been performed. The reaction proceeds much faster when sodium borohydride is used for cleavage in comparison to rongalite and it can be ascribed to nucleophilic behavior of sodium borohydride.

\section{Supplementary Information}

Crystallographic information (excluding structure factors) has been deposited in the crystallographic information file (CIF) format with the Cambridge Crystallographic Data Centre as supplementary Publication No. CCDC No. 1037866 for compound (2). Copies of this information may be obtained free of charge from the Director, CCDC, 12 Union Road, Cambridge CB2 1EZ, UK (fax: +44 1223 336033; e-mail: deposit@ccdc.cam.ac.uk). The mass and the thermo gravimetric pattern of the compound (2) have been listed. All additional information pertaining to characterization of the compound using NMR $\left({ }^{1} \mathrm{H},{ }^{13} \mathrm{C}\right.$,
${ }^{77} \mathrm{Se}$; figures S1, S2 and S3, respectively), ESI-MS technique (figures S4 and S5) and thermogravimetric pattern (figure S6) are given in the supporting information available at www.ias.ac.in/chemsci.

\section{Acknowledgements}

We gratefully acknowledge the financial support for this work from Council of Scientific and Industrial Research (CSIR), New Delhi, vide sanction No. F.No.10-2(5)/2004(ii)-E.U.II dated 28-08-2004.

\section{References}

1. Posser T, Kaster P M, Barauna S C, Rocha B T J, Rodrigues A L S and Leal R B 2009 Eur. J. Pharma. 602 85

2. Krief A, Abel W W, Stone F G A and Wilkinson G (Eds.) 1995 In Comprehensive Organomettalic Chemistry (Oxford, UK: Permagon) p. 515

3. Mugeh G, duMont W W and Sies H 2001 Chem. Rev. 1012125

4. Nayek H P, Massa W and Dehnen S 2010 Inorg. Chem. 49144

5. Mugeh G, Panda A and Singh H B 2000 Proc. Indian Acad. Sci. (Chem. Sci.) 112239

6. Silvestre F, Danielski L G, Michels M, Florentino D, Vieira A, Souza L, Cardoso L C, Schraider R, Rezin G T, Vuolo F, daRocha J B, Barichello T, Quevedo J, DalPizzol F and Petronilho 2014 Neurotox. Res. 26382

7. Mohammadi E and Movassagh B 2014 Tetrahedron Lett. 551613

8. Plano D, Baquedeno Y, Ibanez E, Jimenez I, Palop J A, Spallholz J E and Sanmartin C 2010 Molecules 157292

9. Prigol M, Luchese C and Nogueira C W 2009 Cell Biochem. Funct. 27216

10. Naithani R 2008 Mini Reviews in Med. Chem. 8657

11. Shen L, Shin K M, Lee K T and Jeong J H 2004 Arch. Pharm. Res. 27816

12. Mlochowski J, Gryglewski, Inglot A D, Jakubowski A, Juchniewicz L and Kloc K 1996 Eur. J. Org. Chem. 1751

13. Cembrzynska-Nowak M, Szklarz E and Inglot A D 1997 J. Interferon Cytokine Res. 17609

14. Tianfeng C, Yum-Shing W, Wenjie Z and Jie L 2009 Chem. Biol. Interact. 18054

15. Micale N, Zappala M and Grasso S 2002 Farmaco-II 57 853

16. Araujo J M and Brondani D J 2005 Cheminform 361522

17. Lages A S, Silva K C, Miranda A L P and Fraga C A M 1998 Eur. J. Bioorg. Med. Chem. Lett. 8183

18. Van Mellaert H, Loof A D and Jurd L 1983 Entomol. Exp. Appl. 3383

19. Zapata-Sudo G, Pereira L S, Beiral J V H, Kummerle A E, Raimundo M J, Antunes F, Sudo R T, Barreiro J E and Fraga A M C 2010 Am. J. Hypertens. 23135

20. Bhasin K K, Arora E, Kaur K, Kang S K, Gobel M, Klapoetke T and Mehta S K 2009 Tetrahedron 65247

21. Bhalla A, Nagpal Y, Kumar R, Mehta S K, Bhasin K K and Bari S S 2009 J. Organomet. Chem. 694197 
22. Bhalla A, Venugopalan P, Bhasin K K and Bari S S 2007 Tetrahedron 633195

23. Sheldrick G M, SADABS: Program for absorption correction using area detector data, University of Göttingen, Germany (1996)

24. Sheldrick G M, SHELXL-97, A Program for Refining Crystal Structures, University of Göttingen, Germany (1997)

25. Hua G, Li Y, Fuller L A, Alexandra A M Z and Woolins J D 2009 Eur. J. Org. Chem. 101612

26. Movassagh B and Mirshojaei F 2003 Montash. für. Chem. 134831
27. Kumar S, Helt J C P, Autschbach J and Detty M R 2009 Organometallics 283426

28. Sadek A S, Basmadjian P G, Rieger A J, Hsu M P and Ice D R 1984 Int. J. Appl. Radiat. Isot. 3535

29. Lewicki J W, Günther W H H and Chu J Y C 1978 J. Org. Chem. 432672

30. Bhasin K K, Arora E, Mehta S K and Klapoetka T M 2011 J. Organomet. Chem. 696835

31. Back T G and Codding P W 1983 Can. J. Chem. 612749

32. Wirth T 1998 Molecules 3164

33. Wilson S R, Zucker P A, Huang R R C and Spector A 1989 J. Am. Chem. Soc. 1115936 